\title{
Asialogangliosides as Differentiation Markers of Rat Erythropoietic and Granulopoietic Cells in Rat Bone Marrow. - Flow Cytometric Analysis of Rat Bone Marrow Cells Using Anti-Asialoganglioside Antibodies-
}

\author{
Hirohisa Kimura, Takao Taki, Shyoji Hoshi*, Shyoji Yamamoto* and \\ Makoto Matsumoto ${ }^{1}$ \\ Department of Biochemistry, Shizuoka College of Pharmacy, Oshika, Shizuoka \\ 422, and *Clinical Laboratory, Shizuoka Saiseikai Hospital, Oshika, Shizuoka \\ 422, Japan
}

\begin{abstract}
Flow cytometric analysis using anti-glycolipid antiserum was used on rat bone marrow cells to determine the relation between the glycolipid species expressed on cell surfaces and cell differentiation. Four kinds of antibodies against gangliotriaosylceramide $\left(\mathrm{Gg}_{3} \mathrm{Cer}\right)$, gangliotetraosylceramide $\left(\mathrm{Gg}_{4} \mathrm{Cer}\right.$ ), fucogangliotetraosylceramide (IV ${ }^{2} \alpha \mathrm{Fuc}-\mathrm{Gg}_{4} \mathrm{Cer}$ ) and $\mathrm{IV}^{3} \alpha \mathrm{Gal}$ fucogangliotetraosylceramide (IV ${ }^{3} \alpha \mathrm{GalIV}^{2} \alpha \mathrm{Fuc}-\mathrm{Gg}_{4} \mathrm{Cer}$, blood group B lipid) were used. The cells sorted out by each anti-glycolipid antiserum were stained with May-Grünwald-Giemsa reagent and identified by microscopy. In the erythropoietic group, only polychromatic erythroblasts had these four glycolipids on their cell surfaces; none appeared on differentiated erythrocytes. These glycolipids were expressed during the early stages of immature granulocytes, especially in the promyelocyte and myelocyte stages of eosinophilic and neutrophilic granulocytes. Very limited populations of lymphocytes were sorted out as asialoganglioside-expressing cells. We concluded that asialogangliosides are useful differentiation markers for the erythropoietic and granulopoietic cells of rat bone marrow, and that anti-asialoganglioside antibody-flow cytometry is a very useful technique with which to isolate immature granulocytes and erythropoietic cells from rat bone marrow cells.
\end{abstract}

\footnotetext{
Abbreviations used: $\operatorname{LacCer}, \operatorname{Gal}(\beta 1-4) \mathrm{Glc}(\beta 1-1) \mathrm{Cer} ; \mathrm{Gb}_{3} \mathrm{Cer}, \mathrm{Gal}(\alpha 1-4) \mathrm{Gal}(\beta 1-4) \mathrm{Glc}(\beta 1-1) \operatorname{Cer}$; $\mathrm{Gg}_{3} \mathrm{Cer}$, GalNAc $(\beta 1-4) \mathrm{Gal}(\beta 1-4) \mathrm{Glc}(\beta 1-1) \mathrm{Cer} ; \mathrm{Gg}_{4} \mathrm{Cer}, \operatorname{Gal}(\beta 1-3) \operatorname{GalNAc}(\beta 1-4) \operatorname{Gal}(\beta 1-4) \mathrm{Glc}(\beta 1-$ 1)Cer; $\mathrm{nLc}_{4} \mathrm{Cer}, \operatorname{Gal}(\beta 1-4) \operatorname{GlcNAc}(\beta 1-3) \mathrm{Gal}(\beta 1-4) \mathrm{Glc}(\beta 1-1) \mathrm{Cer} ; \mathrm{GM}_{1_{\mathrm{a}}}$, Gal $(\beta 1-3) \operatorname{GalNAc}(\beta 1-4)$ $[\mathrm{NeuAc}(\alpha 2-3)] \mathrm{Gal}(\beta 1-4) \mathrm{Glc}(\beta 1-1) \mathrm{Cer} ; \quad \mathrm{IV}^{2} \alpha \mathrm{Fuc}-\mathrm{Gg}_{4} \mathrm{Cer}, \operatorname{Fuc}(\alpha 1-2) \mathrm{Gal}(\beta 1-3) \mathrm{GalNAc}(\beta 1-4) \mathrm{Gal}(\beta 1-$

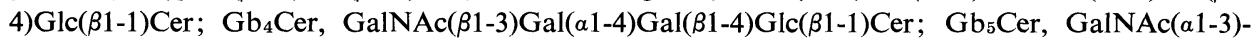
GalNAc $(\beta 1-3) \operatorname{Gal}(\alpha 1-4) \mathrm{Gal}(\beta 1-4) \mathrm{Glc}(\beta 1-1) \mathrm{Cer}$; blood group B lipid, Gal( $\alpha 1-3)[\mathrm{Fuc}(\alpha 1-2)] \mathrm{Gal}(\beta 1-$ 3)GalNAc $(\beta 1-4) \mathrm{Gal}(\beta 1-4) \mathrm{Glc}(\beta 1-1) \mathrm{Cer}$; PBS, Phosphate-buffered saline; FITC, fluoresceine isothiocyanate; $\mathrm{CF}$, complement fixation. The nomenclature of Svennerholm for gangliosides (4) is used throughout.
}

1. To whom all correspondence should be addressed. 
Cell differentiation alters the chemical composition, antigenic expression and architecture of cell surface glycolipids $(1,2,7,12)$. In rat bone marrow cells, the asialogangliosides $\mathrm{Gg}_{3} \mathrm{Cer}, \mathrm{Gg}_{4} \mathrm{Cer}$, and $\mathrm{IV}^{2} \alpha \mathrm{Fuc}-\mathrm{Gg}_{4} \mathrm{Cer}$ are major components of the neutral glycolipids (5). A main glycolipid in rat bone marrow cells recently has been shown to be a blood group B-active lipid whose back bone is a gangliotetraosylceramide (8). Based on results of chemical analyses of glycolipids and on a biosynthetic study (5), we proposed that glycolipid biosynthesis via asialogangliosides constitutes the main biosynthetic pathway in rat bone marrow cells (6). In addition, synthesis via $\mathrm{GM}_{3}$ as well as the asialoganglioside pathway was present. In earlier study, we demonstrated developmental changes in $\mathrm{GM}_{3}$ and $\mathrm{GM}_{1 \mathrm{~b}}$ synthesis in rat bone marrow cells (9). All these findings indicate that a metabolic change of glycolipid biosynthesis from the pathway via asialoganglioside to that via $\mathrm{GM}_{3}$, which leads to the formation of $\mathrm{GM}_{1 \mathrm{a}}$ and $\mathrm{GD}_{1 \mathrm{a}}$, may take place during the differentiation or maturation of bone marrow cells.

Bone marrow cells are composed of a varied population of granulopoietic cells, erythropoietic cells, megakaryocytic cells, monocytes and lymphocytes, and the various degrees of maturation and differentiation produce very complicated cell populations. We therefore have tried to discriminate among these cells on the basis of the glycolipid species expressed on their surfaces. Indirect immunofluorescence and flow cytometry with anti-asialoganglioside antiserum were used to sort out particular cell populations from the total bone marrow sample. We here show that asialogangliosides are useful markers for sorting out immature erythropoietic and granulopoietic cells in rat bone marrow.

\section{MATERIALS AND METHODS}

Anti-glycolipid antisera. Anti-glycolipid antisera were prepared as described elsewhere (10). The glycolipids used as antigens and the specificities of the anti-glycolipid antisera are listed in Table 1. To prevent cross reactions with other glycolipids, the antiserum was diluted 50-fold with PBS when immunostaining was done.

Rat bone marrow cells. Rat bone marrow cells were obtained from femurs of 4-week-old

TABLE 1. SPECIFICITIES OF ANTI-GLYCOLIPID ANTIBODIES

\begin{tabular}{|c|c|c|c|c|c|}
\hline \multirow{2}{*}{ Glycolipids tested } & \multicolumn{5}{|c|}{ Complement fixation titer with antibody against } \\
\hline & $\mathrm{Gg}_{4} \mathrm{Cer}$ & $\mathrm{Gg}_{3} \mathrm{Cer}$ & $\mathrm{nLc}_{4} \mathrm{Cer}$ & Fuc-Gg ${ }_{4} \mathrm{Cer}$ & Blood group B \\
\hline LacCer & $2^{1}$ & $2^{2}$ & $2^{3}$ & $2^{1}$ & $2^{1}$ \\
\hline $\mathrm{Gb}_{3} \mathrm{Cer}$ & 0 & N.T & N.T & $2^{1}$ & $2^{2}$ \\
\hline $\mathrm{Gg}_{3} \mathrm{Cer}$ & 0 & $2^{7}$ & N.T & 0 & $2^{1}$ \\
\hline $\mathrm{Gg}_{4} \mathrm{Cer}$ & $2^{?}$ & $2^{2}$ & $2^{2}$ & 0 & $2^{3}$ \\
\hline $\mathrm{nLc}_{4} \mathrm{Cer}$ & $2^{2}$ & 0 & $2^{7}$ & 0 & $2^{1}$ \\
\hline $\mathrm{GM}_{1 \mathrm{a}}$ & 0 & $2^{2}$ & $2^{2}$ & 0 & N.T \\
\hline Fuc- $\mathrm{Gg}_{4} \mathrm{Cer}$ & 0 & N.T & N.T & $2^{7}$ & $2^{4}$ \\
\hline $\mathrm{Gb}_{4} \mathrm{Cer}$ & $2^{1}$ & $2^{1}$ & N.T & $2^{2}$ & N.T \\
\hline $\mathrm{Gb}_{5} \mathrm{Cer}$ & 0 & N.T & N.T & N.T & N.T \\
\hline Blood group B lipid & N.T & N.T & N.T & N.T & $2^{7}$ \\
\hline
\end{tabular}

N.T, Not tested; 0 , no cross reaction 
Donryu rats. These cells first were suspended in PBS containing $0.02 \%$ of the disodium salt of EDTA then passed through nylon mesh (70 nm dia.).

Indirect immunofluorescence staining. One milliliter of the rat bone marrow cell suspension $\left(1.7 \times 10^{7}\right.$ cells $\left./ \mathrm{ml}\right)$ was incubated at $4^{\circ} \mathrm{C}$ for $30 \mathrm{~min}$ with $1 \mathrm{ml}$ of anti-glycolipid antiserum (diluted 50-fold with PBS), after which the cells were spun down and washed with PBS. One milliliter of FITC-conjugated sheep anti-rabbit IgG (purchased from Cappel Lab. Inc. and diluted 50-fold with PBS before use) was added to the cell pellets and shaken well to make a suspension. The reaction was took place at $4^{\circ} \mathrm{C}$ for $30 \mathrm{~min}$, after which the cells were washed as described above and suspended in PBS. The same procedure was used for the control experiment except that the anti-glycolipid antiserum was replaced with PBS or antilactoneotetraosylceramide antiserum. Cells incubated with the antisera and FITC-labeled second antibody were analyzed by flow cytometry.

Flow cytometry. Flow cytometry and sorting out were done with a Shomedic cell sorter (CS-20, Showadenko, Japan). Before application of the suspension, the cells were filtered through mesh ( $40 \mathrm{~nm}$ dia.) to avoid clogging the nozzle of the instrument; this procedure removed megakaryocytes. The flow speed used to sort out the cells was $7 \mathrm{~m} / \mathrm{sec}$ in order to prevent damage to the cells. Cells sorted out by each anti-glycolipid antiserum were identified by microscopy after they had been stained with May-Günwald-Giemsa staining reagent.

\section{RESULTS AND DISCUSSION}

Scatter profile of rat bone marrow cells. A light-scatter profile of rat bone marrow cells is shown in Fig. 1. Bone marrow cells can be placed in three classes according to size. S(small size), M(middle size) and L(large size), having been sorted in a cell sorter and identified by microscopy after staining with May-Grünwald-Giemsa reagent. $\mathrm{S}$ class, the main component, is composed of mature erythrocytes. $\mathrm{M}$ class contains myelocytes, metamyelocytes, mature granulocytes as granulopoietic cells, polychromatic erythroblasts as erythropoietic cells and lymphocytes. Proerythroblasts, myeloblasts, promyelocytes and some myelocytes make up the L class. In general, large cells are immature when compared with small size cells. No megakaryopoietic cells are shown in Fig. 1 because these cells were too large to pass through the filter of the cell sorter.

Flow cytometric analysis of rat bone marrow cells stained with anti-glycolipid antiserum and FITC-labeled second antibody. The bone marrow cells were allowed to react with various anti-glycolipid antisera and the FITC-labeled second antibody, obtained was analyzed by flow cytometry. Each cytometric analysis shows the characteristic profile of the anti-glycolipid antiserum used as the first antibody (Fig. 2b-e). The profile of the $\mathrm{Gg}_{3}$ Cer-expressing cell is shown in Fig. 2b. Most $\mathrm{L}$ class cells and some $\mathrm{M}$ class ones were separated as fluorescence-stained cells.

Cells that reacted with anti-Gg $\mathrm{G}_{4} \mathrm{Cer}$ antiserum (Fig. 2c) show a profile similar to that of the anti- $\mathrm{Gg}_{3} \mathrm{Cer}$-expressing cells, but some $\mathrm{L}$ and $\mathrm{M}$ class cells were stained more heavily than the rest of the cells.

$\mathrm{IV}^{2} \alpha$ Fuc-Gg $\mathrm{G}_{4}$ Cer-expressing cells mainly were detected in the L class (Fig. 2d). Both $\mathrm{M}$ and $\mathrm{L}$ class cells were stained with anti-blood group B lipid antiserum, and some of them were stained more intensively than others (Fig. 2e).

As stated, each anti-glycolipid antiserum gave a characteristic flow cytometry profile, but it should be noted that L class cells were stained well by all the antibodies, whereas $\mathrm{S}$ cells were not. This is evidence that blastic cells in rat bone marrow express 


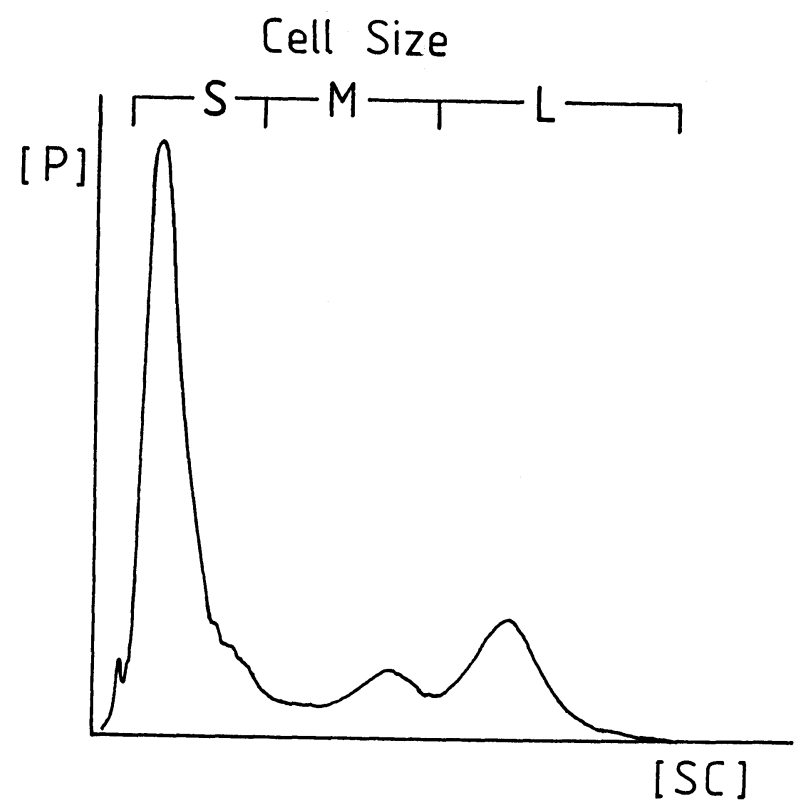

Fig. 1. Forward light-scatter profile of rat bone marrow cells analyzed by flow cytometry. Cell size is plotted against cell population. $[\mathrm{SC}]$ is the light-scatter intensity and [P] the cell population. Cells could be classified into three size types; small (S), middle (M) and large (L).

these glycolipids on their surfaces.

Identification of FITC-stained bone marrow cells. The fluorescence-stained cells were sorted out and identified by microscopy. Results are summarized in Fig. 3b-e, the distribution of the bone marrow cells of 4-week-old rats being shown in Fig. 3a.

In the erythropoietic cells, all the glycolipids tested were expressed only during the polychromatic erythroblast stage. Neither more immature nor differentiated erythrocytes expressed asialogangliosides on their cell surfaces. In eosinophilic cells, all the glycolipids used as antigens appeared mainly during the myelocyte stage, and $\mathrm{Gg}_{4} \mathrm{Cer}$ was expressed weakly on the cell surfaces of metamyelocytes. This phenomenon indicates that asialogangliosides disappear as eosinophilic cells mature. Glycolipid expression on the surfaces of neutrophilic cells during maturation differed from that of eosinophilic cells. Asialogangliosides appeared during the promyelocyte and myelocyte stages of neutrophilic cells, disappearing from metamyelocytes and band cells. Later there was a sudden appearance of these glycolipids, except for the blood group B lipid, in differentiated segmented cells.

Fig. 2. Flow cytometry analysis of rat bone marrow cells using various anti-glycolipid antisera. The cells were allowed to react with PBS (a), anti-Gg ${ }_{3} \mathrm{Cer}$ antiserum (b), anti-Gg ${ }_{4} \mathrm{Cer}$ antiserum (c), anti-IV ${ }^{2} \alpha$ Fuc-Gg $\mathrm{G}_{4}$ Cer antiserum (d), and anti-blood group B lipid antiserum (e). Fluorescence intensity [FL] on the $\mathrm{X}$ axis is shown by the log scale. Cell size [SC] on the $\mathrm{Y}$ axis and cell population [P] on the $Z$ axis are shown by linear scales. Cells in the area delineated by the dotted lines were sorted and analyzed by microscopy after staining them with May-Grünwald Giemsa reagent. Cells showing stains for anti- $\mathrm{Gg}_{4} \mathrm{Cer}$ antiserum and anti-blood group B antiserum were divisible into two classes; a weakly stained class (W) and an intensively stained class (I). 

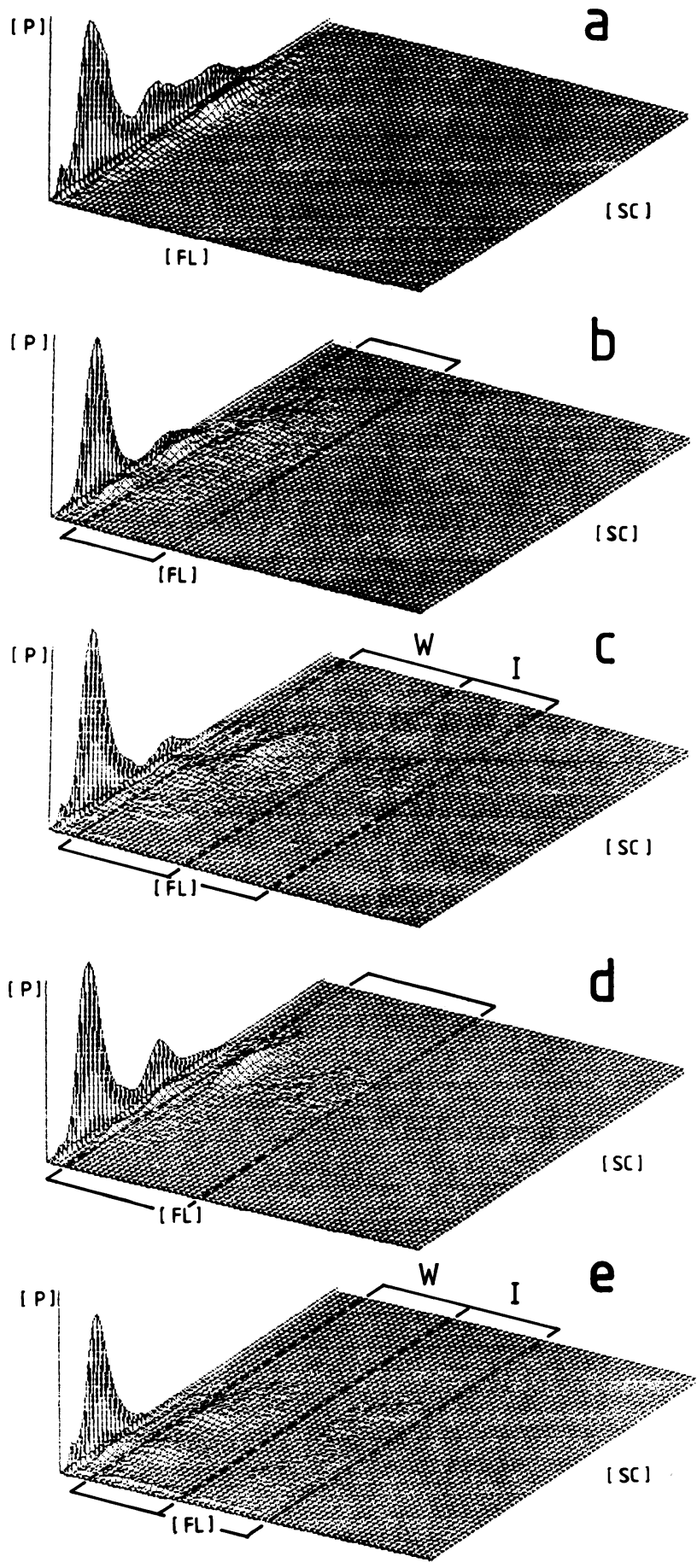
Although lymphocytes accounted for more than $30 \%$ of the bone marrow cells (Fig. 3a), those stained with fluorescence were very small percentages in all cases $(3-5 \%)$.

Based on these observations, the glycolipid biosynthetic pathway via asialoganglioside appears to originate in the early stages of the differentiation of granulocytes and erythropoietic cells; but, these asialogangliosides disappeared from cell surfaces at a particular stage of differentiation (Fig. 3). Our experimental results suggested two possibilities for the disappearance of asialogangliosides post mitosis; that these lipids became cryptic due to alterations in the arrangement of cell surface components during cell differentiation, or that the biosynthetic pathway of glycolipid changes from the pathway via asialogangliosides to another pathway, e.g., via $\mathrm{GM}_{3}$. The second possibility is more likely for erythropoietic cells because no asialogangliosides could be detected on them by immunohistochemical or chemical analyses.

Handa and his colleagues reported the presence of $\mathrm{GM}_{1 \mathrm{a}}$, Fuc-GM $\mathrm{M}_{1}$ and $\mathrm{GD}_{1 \mathrm{a}}$, but not $\mathrm{GM}_{1 \mathrm{~b}}$, on erythrocyte membranes (3). We demonstrated the presence of $\mathrm{GM}_{3}, \mathrm{GM}_{2}$ and $\mathrm{GD}_{1 \mathrm{a}}$ as well as $\mathrm{GM}_{1 \mathrm{~b}}$ on the bone marrow cells (9). Therefore, the ganglioside synthetic pathway via $\mathrm{GM}_{3}$ may be activated at a particular stage of

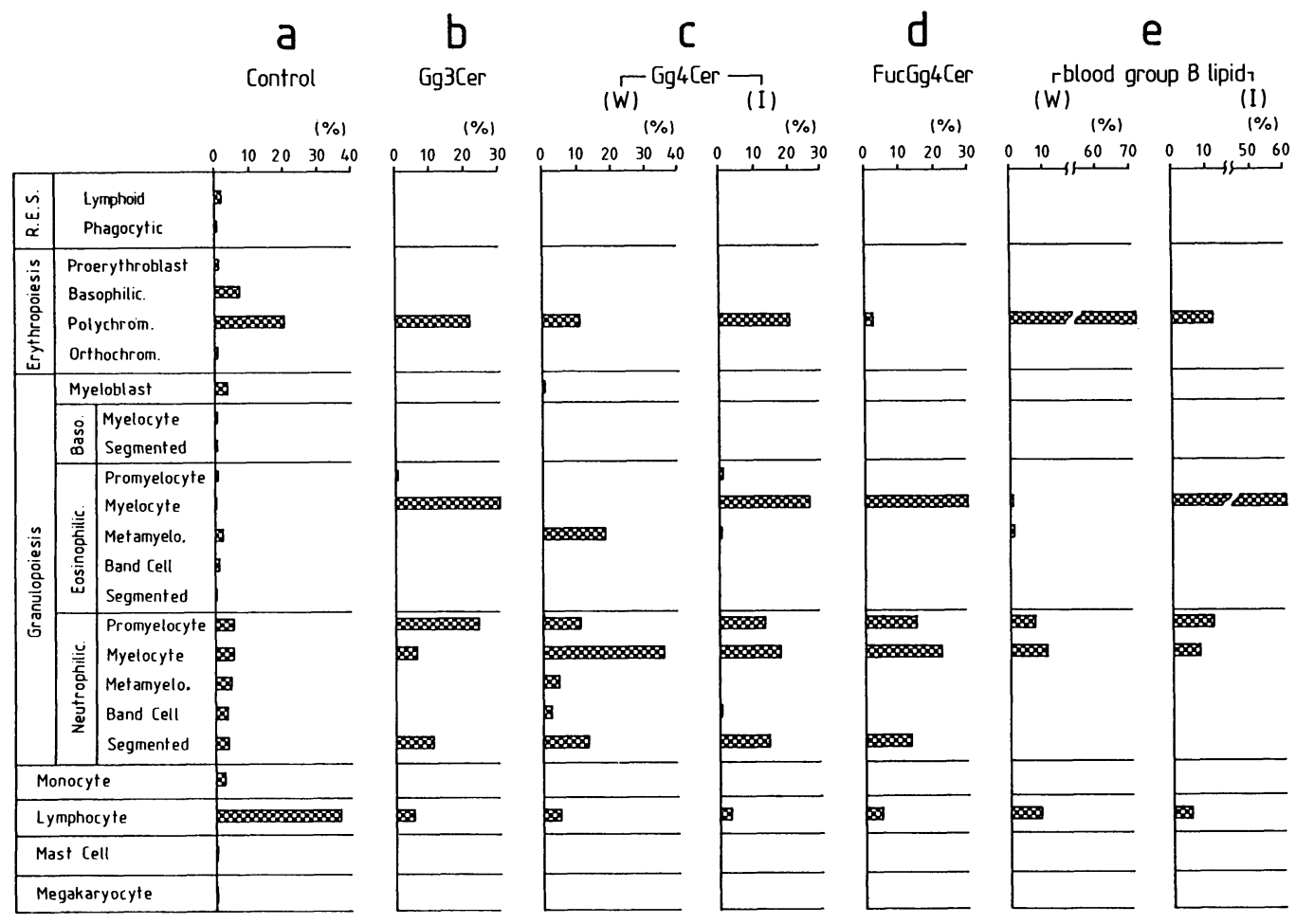

Fig. 3. Distribution of rat bone marrow cells stained with each anti-glycolipid antiserum. Column a: the distribution of rat bone marrow cells (mature erythrocytes were avoided in the counting.). Columns b-e: distributions of rat bone marrow cells sorted out by each anti-glycolipid antiserum against $\mathrm{Gg}_{3} \mathrm{Cer}$ (b), $\mathrm{Gg}_{4} \mathrm{Cer}$ (c), Fuc- $\mathrm{Gg}_{4} \mathrm{Cer}$ (d) and blood group B lipid (e). The W and I shown in columns (c) and (d) indicate weakly stained and intensively stained cells. Approximately three hundred cells were classified in each category. The numbers above each column are the percent of distribution. 
differentiation and replace the pathway via asialogangliosides. In an earlier study (7), we found a dramatic alteration in the glycolipid composition associated with the differentiation of mouse myeloid leukemia cells (Ml) into macrophage-type cells. Gangliotriaosylceramide, a predominant glycolipid in M1 cells, became a minor component and globotriaosylceramide was the major component present in the differentiated cells; also $\alpha$-galactosyltransferase activity increased more than 10 -fold during differentiation. The present data together with our previous observations strongly suggest that differentiation alters the glycolipid biosynthetic pathway.

Hakomori and Kannagi (2) found a stage-dependent expression of various carbohydrate chains during the ontogenic process and the retrogenic expression of these

Erythropoietic cells

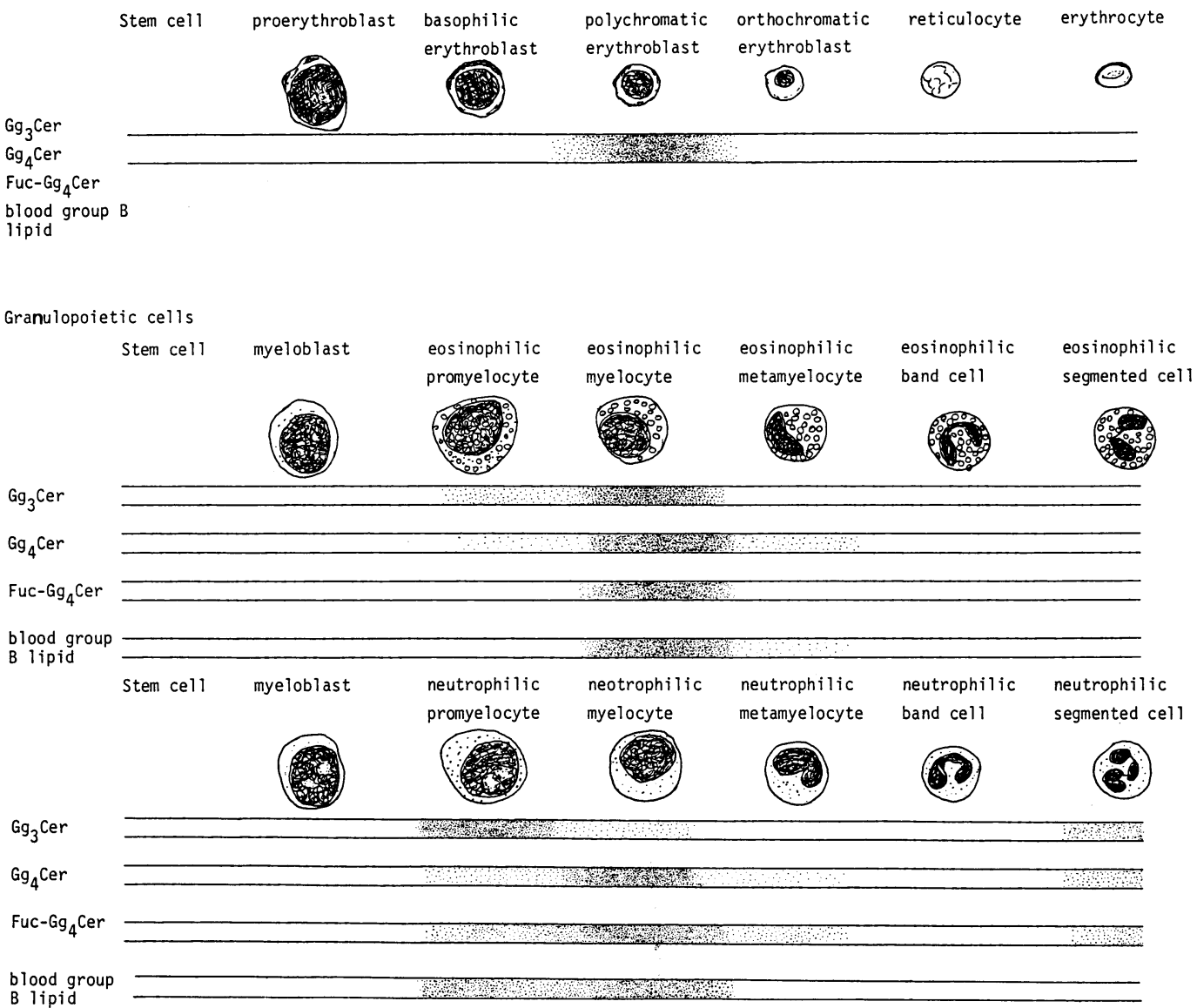

Fig. 4. Schematic profiles of the stage-specific expression of asialogangliosides on rat erythropoietic and granulopoietic cells. In erythropoietic cells, asialogangliosides, including Fuc-Gg $\mathrm{Ger}_{4}$ and blood group B lipid, are expressed on the cell surfaces of polychromatic erythroblasts. In eosinopoietic cells, asialogangliosides are expressed mainly during the myelocyte stage. In neutrophilic granulopoietic cells, $\mathrm{Gg}_{3} \mathrm{Cer}$ is expressed on the cell surface during the promyelocyte and myelocyte stages. The other three glycolipids are expressed mainly during the myelocyte stage. $\mathrm{Gg}_{3} \mathrm{Cer}, \mathrm{Gg}_{4} \mathrm{Cer}$ and Fuc- $\mathrm{Gg}_{4} \mathrm{Cer}$ disappear after the neutrophilic metamyelocyte stage, but appear again on segmented cell surfaces. 
structures in tumor cells; for example, X-hapten (the 3-fucosyllactosamine structure) is assumed to be maximally expressed during the blastocyte stage or later, but to decrease during further development and to be re-expressed at various organ analoges and germ layers. But its expression is limited in later stages and in adult tissues. The expression of X-hapten is greatly enhanced in some tumor cells. In our series of glycolipid studies of rat ascites hepatoma cells $(8,11)$, asialogangliosides including Fuc- $\mathrm{Gg}_{4} \mathrm{Cer}$ and the blood group B lipid were shown to be the major constituents of free-type rat ascites hepatoma cells. The relation between the stage-specific expression of asialogangliosides in rat bone marrow cells and the appearance of these glycolipids in tumor cells is very similar to the idealized version proposed by Hakomori and Kannagi (2). Our data are presented schematically in Fig. 4.

The experimental data reported here also indicate that the anti-asialoganglioside antibody-flow cytometry system is a very useful technique with which to isolate rat bone marrow cells at a particular granulopoietic or erythropoietic stage. For example, eosinophilic myeloblasts are isolated in the fraction stained intensively with the anti-blood group B lipid antiserum, and polychromatic erythroblasts are isolated from the fraction weakly stained by anti-blood group B lipid antiserum (Fig. 3e).

Acknowledgments. We thank Mr. H. Soga and Miss M. Shinoda of Showadenko K.K., for their operation of the cell sorter. This study was supported in part by a Grant-in-Aid for Scientific Research from the Ministry of Education, Science and Culture of Japan.

\section{REFERENCES}

1. НАкомові, S. Glycosphingolipids in cellular interaction, differentiation, and oncogenesis. Ann. Rev. Biochem. 50, 733-764, 1981

2. HaKomori, S. and R. KanNagi. Glycosphingolipid as tumor-associated and differentiation markers. J. Natl. Cancer Inst. 71, 231-251, 1983

3. Rokukawa, C., Y. Kushi, K. Ueno and S. Handa. Structural study on gangliosides from rat liver and erythrocytes. J. Biochem. 92, 1481-1488, 1982

4. Svennerholm, L. The gangliosides. J. Lipid Res. 5, 145-155, 1964

5. TAKI, T., R. KAMAdA and M. Matsumoto. Glycosphingolipid biosynthesis through asialogangliosides in rat bone marrow cells. J. Biochem. 91, 665-674, 1982

6. TAKi, T., R. Kamada and M. Matsumoto. Glycosphingolipid biosynthesis in rat bone marrow cells. In New Vistas in Glycolipid Research, eds. Makita, A., S. Handa, T. Taketomi and Y. Nagai, Plenum Press, New York, pp. 179-193, 1982

7. Taki, T., M. Kawamoto, H. Seto, N. Noro, T. Masuda, R. Kannagi and M. Matsumoto. Differentiation-associated changes of glycolipid composition and metabolism in mouse myeloid leukemia cells. Induction of globotriaosylceramide and a galactosyltransferase. J. Biochem. 94, 633-644, 1983

8. Taki, T., H. Kimura, S. Gasa, M. Nakamura and M. Matsumoto. A new type of blood group B active glycosphingolipid in rat bone marrow cells. Occurrence of the glycolipid in rat immunocytes and ascites hepatoma. J. Biol. Chem. 260, 6219-6225, 1985

9. TAKi, T., H. Kimura, C. TAKatsuka and M. Matsumoto. Developmental changes of ganglioside compositions and biosynthesis in rat bone marrow cells, spleen and thymus. J. Biochem. 94, 925-930, 1983

10. TAKi, T., K. TAKagi, R. Kamada, M. Matsumoto and K. Kojima. Study of asialogangliosides on surface membranes of rat bone marrow cells and macrophages. J. Biochem. 90, 16521660,1981

11. Taki, T., Y. Hirabayashi, Y. Ishiwata, M. Matsumoto and K. Kojima. Biosynthesis of different gangliosides in two types of rat ascites hepatoma cells with different degree of cell 
adhesiveness. Biochim. Biophys. Acta 572, 113-120, 1979

12. Willison, K.R., R.A. Karol, A. Suzuki, S.K. Kundu and D.M. Marcus. Neutral glycolipid antigens as developmental markers of mouse teratocarcinoma and early embryos: an immunologic and chemical analysis. J. Immunol. 129, 603-609, 1982

(Received for publication, January 31, 1986) 